\title{
Amino acid requirements of pigs. 1. Requirements for methionine + cystine, threonine and tryptophan of fast-growing boars and gilts, fed ad libitum
}

\author{
N. P. LENIS 1 , J. TH. M. VAN DIEPEN ${ }^{1} \&$ P. W. GOEDHART2 2 \\ 1 Research Institute for Livestock Feeding and Nutrition, P.O. Box 160, NL 8200 AD \\ Lelystad, Netherlands \\ 2 Agricultural Mathematics Group, P.O. Box 100, NL 6700 AC Wageningen, Netherlands
}

Received 1 March 1990; accepted 9 May 1990

\begin{abstract}
In formulating diets for good growth performance and avoiding wasteful oversupply of dietary protein, it is important to estimate the pig's requirements for essential amino acids more accurately. With this knowledge crude protein levels in diets can be lowered with adequate supplementation of synthetic amino acids, which can contribute substantially to improvement of nitrogen utilization and thus reduction of nitrogen excretion by pigs. To establish the requirements for apparent digestible methionine + cystine, threonine and tryptophan three similar feeding experiments, each with 64 growing pigs in the live weight range 35-105 $\mathrm{kg}$, were carried out. The pigs were housed individually and were fed ad libitum. Each experiment comprised four treatments consisting of the same basal diet with three levels of supplementation of the amino acid under study (DL-methionine, L-threonine, DL-tryptophan, respectively). In each experiment the amino acid used to supplement the basal diet was the first limiting amino acid. The diets contained $8.6-8.8 \mathrm{~g} \mathrm{~kg}^{-1}$ total lysine, corresponding with 7.1-7.2 $\mathrm{g} \mathrm{kg}^{-1}$ apparent faecal digestible lysine and on average $8.90 \mathrm{MJ} \mathrm{kg}^{-1} \mathrm{NE}_{\mathrm{f}}$. Daily gain, feed intake, feed conversion ratio and carcass quality were the response criteria. In digestibility experiments the apparent faecal digestibility of organic matter, protein and amino acids of one or two diets from each feeding experiment was determined with four pigs each. The average daily gain of the optimally supplemented groups was 875 grams and feed conversion ratio 2.84 . For maximum growth performance of pigs between 35 and $105 \mathrm{~kg}$, the requirement for total methionine + cystine, threonine and tryptophan, relative to total lysine supply, was assessed to be approximately $60 \%, 66 \%$ and $19 \%$, respectively. On a faecal digestible basis, requirements were approximately $58 \%, 63 \%$ and $19 \%$, relative to faecal digestible lysine, respectively.
\end{abstract}

Keywords: pigs, amino acid requirements, amino acid digestibility, methionine + cystine, threonine, tryptophan, synthetic amino acids 


\section{Introduction}

In practical pig feeding, most diets are formulated by linear programming. For protein, this usually occurs on the basis of allowances for lysine and methionine + cystine or digestible lysine and methionine + cystine. In practical nutrition in the Netherlands digestible amino acid values have been based on faecal measurements, on a temporary basis (Lenis, 1983; CVB, 1984; Lenis 1989). In formulating diets with the available feedstuffs, it is usually impossible to meet the needs for these amino acids without considerable oversupply of some others. So the amino acid composition of pig diets rarely corresponds closely to 'ideal protein composition' as suggested by the Agricultural Research Council (ARC) (1981) and Moughan \& Smith (1984). An excessive supply of amino acids can be responsible for the major part of urinary nitrogen excretion and for inefficient utilization of dietary protein. Because of pollution problems there is a need for reduction of nitrogen excretion in animal husbandry (Lenis, 1989). The key to reduced nitrogen excretion is a better balance of the amino acids in dietary protein. Basing dietary protein quality on the (ileal) digestible amino acid content (Sauer \& Ozimek, 1986; van Weerden, 1989), and especially lowering dietary protein levels by supplementing with synthetic amino acids will contribute to reduction of $\mathrm{N}$ excretion by pigs. In this way, oversupply of amino acids can be minimized and the efficiency of nitrogen utilization improved.

In order to achieve this, the requirements for essential amino acids of pigs need to be known more accurately than at present. The requirement for lysine of starter pigs and growing-finishing pigs is considered to have been studied adequately (Lenis \& Metz, 1984; Williams et al., 1984; Yen et al., 1986a, b; Fuller et al., 1986; Bourbon \& Henry, 1988). For other essential amino acids, however, information about requirements of growing-finishing pigs having a high growth performance is conflicting or scarce. For methionine + cystine the ARC (1981) estimate is $50 \%$ relative to total lysine. This is considerably lower than the estimates of Günther \& Badewien (1987), Roth \& Kirchgessner (1987), Wang \& Fuller (1989), Fuller et al. (1989) and Wang \& Fuller (1990). The ARC (1981) estimate for the threonine requirement, being $60 \%$ relative to total lysine, is also substantially lower than the estimates of Wang \& Fuller (1989) and Fuller et al. (1989), i.e. 72 and $75 \%$ respectively. Günther \& Badewien (1987) and Wang \& Fuller (1990) concluded a threonine requirement of growing pigs of 65 and $64 \%$ respectively relative to total lysine. Further experiments in literature into the threonine requirement of growing-finishing pigs, in which no other amino acids limited maximum growth performance, are scarce.

This is also true for tryptophan. Henry et al. (1986) reported maximum growth performance of pigs between 15 and $40 \mathrm{~kg}$ live weight at $1.58 \mathrm{~g} \mathrm{~kg}^{-1}$ dietary tryptophan. Kiener et al. (1988) concluded a tryptophan requirement of growing pigs of $1.7 \mathrm{~g} \mathrm{~kg}^{-1}$ diet under lysine-deficient conditions. It is clear that difficulties in measurement of tryptophan have led to difficulties in interpreting results from tryptophan experiments in literature. Wang \& Fuller (1989) and Fuller et al. (1989) estimated the tryptophan requirement to be $18-19 \%$ relative to total lysine. But in 
recent experiments Wang \& Fuller (1990) concluded $20 \%$. Also studies on young pigs (Kirchgessner \& Roth, 1985; Schutte et al. 1988) suggest that the tryptophan requirement of pigs is above the value relative to total lysine of $15 \%$ as suggested by ARC (1981).

Because a reduced protein supply following lysine supplementation may lead to a shortage of methionine + cystine, threonine and tryptophan, minimum requirements of these amino acids relative to lysine should be known. Therefore a series of three experiments was conducted to determine the requirements for apparent digestible methionine + cystine, threonine and tryptophan, in fattening gilts and boars in the weight range $35-105 \mathrm{~kg}$.

\section{Material and methods}

The experimental design was similar for the three trials. The experiments were carried out at the Experimental Farm for Pig Production at Raalte. Methionine + cystine were studied in Experiment 1, threonine in Experiment 2 and tryptophan in Experiment 3.

\section{Animals and housing}

Each experiment comprised 64 individually housed crossbred $(\mathrm{GY} \times(\mathrm{GY} \times \mathrm{NL}))$ pigs ( 32 boars and 32 gilts), which were born and raised at the Experimental Farm. At about $22 \mathrm{~kg}$ live weight the animals were allotted to 4 experimental groups according to a randomized block design, considering initial weight and litter association. Each block consisted of pigs of one sex only. From weaning up to about $30 \mathrm{~kg}$ live weight the pigs were fed a commercial starter feed ad libitum. From $30 \mathrm{~kg}$ to $35 \mathrm{~kg}$ the pigs were accustomed to the experimental diets.

The pig unit was ventilated and artificially heated up to a temperature which was always above the minimum critical temperature. Each pen had a partly slatted floor, a feeding trough and a nipple drinker, which was situated in the back of the pen.

\section{Experimental design}

The experimental design of the 3 experiments is given in Table 1 . In each experiment 4 treatments were applied: a basal diet with a low concentration of one amino acid and 3 levels of supplementation with the synthetic amino acid concerned (DLmethionine, L-threonine and DL-tryptophan, respectively). DL-tryptophan was assumed to be $80 \%$ utilized (Baker et al., 1971). The analysed dietary concentration of experimental amino acid was very close to the predicted concentration. Only in Experiment 1 minor differences occurred between analysed and calculated dietary levels of methionine + cystine.

The start of the experimental period was at about $35 \mathrm{~kg}$ live weight. The animals were slaughtered at about $105 \mathrm{~kg}$. Daily gain, feed conversion ratio, feed intake and carcass quality were the response criteria. 
Table 1. Experimental design of the three experiments.

\begin{tabular}{|c|c|c|c|c|c|}
\hline \multirow[t]{2}{*}{ Treatment } & \multirow[t]{2}{*}{ Diet } & \multirow{2}{*}{$\begin{array}{l}\text { Amino acid } \\
\text { supplementation } \\
\left(\mathrm{g} \mathrm{kg-1}^{-1}\right)\end{array}$} & \multicolumn{3}{|c|}{$\begin{array}{l}\text { Analysed levels of amino acids } \\
\left(\mathrm{g} \mathrm{kg}^{-1)}\right.\end{array}$} \\
\hline & & & methionine & cystine & meth. + cys \\
\hline \multicolumn{6}{|c|}{ Experiment 1} \\
\hline 1 & Basal diet & - & 2.1 & 2.4 & 4.5 \\
\hline 2 & Basal diet + & $0.41 \mathrm{DL}$-methionine & 2.5 & 2.4 & 4.9 \\
\hline 3 & Basal diet ++ & $0.82 \mathrm{DL}$-methionine & 2.9 & 2.4 & 5.3 \\
\hline 4 & Basal diet +++ & 1.23 DL-methionine & 3.3 & 2.4 & 5.7 \\
\hline \multicolumn{6}{|c|}{ Experiment 2} \\
\hline 1 & Basal diet & - & \multicolumn{3}{|l|}{4.7 threonine } \\
\hline 2 & Basal diet + & $0.5 \mathrm{~L}$-threonine & \multicolumn{3}{|l|}{5.2 threonine } \\
\hline 3 & Basal diet ++ & $1.0 \mathrm{~L}$-threonine & \multicolumn{3}{|l|}{5.7 threonine } \\
\hline 4 & Basal diet $t+t$ & 1.5 L-threonine & \multicolumn{3}{|l|}{6.2 threonine } \\
\hline \multicolumn{6}{|c|}{ Experiment 3} \\
\hline 1 & Basal diet & - & \multicolumn{3}{|c|}{1.15 tryptophan } \\
\hline 2 & Basal diet + & 0.31 DL-tryptophan & \multicolumn{3}{|c|}{1.40 tryptophan } \\
\hline 3 & Basal diet ++ & 0.62 DL-tryptophan & \multicolumn{3}{|c|}{1.65 tryptophan } \\
\hline 4 & Basal diet +++ & 0.93 DL-tryptophan & \multicolumn{3}{|c|}{1.90 tryptophan } \\
\hline
\end{tabular}

\section{Diets and feeding}

The diets were composed on the basis of proximate analysis and amino acid analysis in the feedstuffs used. The proportions of feedstuffs and chemical composition of the basal diets in the three experiments are shown in Table 2. Lysine concentration in the diets was between 8.6 and $8.8 \mathrm{~g} \mathrm{~kg}^{-1}$. The crude protein contents in the diets of the Experiments 2 and 3 were rather low (137 and $136 \mathrm{~g} \mathrm{~kg}^{-1}$, respectively) in order to get low concentrations of threonine and tryptophan, respectively, in the basal diets. Diets were supplemented with L-lysine $\mathrm{HCl}$, DL-methionine, Lthreonine, DL-tryptophan and L-isoleucine in order to be sure that no other amino acids than the amino acid studied were limiting. The supplementation of synthetic amino acids was made in a specially prepared pre-mix, together with minerals and vitamins.

Ten ppm $\mathrm{Cu}$ was added to all diets in the form of copper sulphate. Neither antibiotics nor other growth-promoting agents were included in the diets. The diets were pelleted and given dry in the through. Feed and water were offered ad libitum.

The composition of the starter feed was as follows: crude protein $180 \mathrm{~g} \mathrm{~kg}^{-1}$, faecal digestible lysine $10.3 \mathrm{~g} \mathrm{~kg}^{-1}$, faecal digestible methionine + cystine $6.0 \mathrm{~g}$ $\mathrm{kg}^{-1}$, net energy 9.4 $\mathrm{MJ} \mathrm{NE}_{\mathrm{f}}$.

\section{Measurements}

Live weight and feed intake were recorded weekly. Before slaughter backfat thick- 
Table 2. Proportion of feedstuffs and analysed chemical composition of the basal diets in the three experiments $\left(\mathrm{g} \mathrm{kg}^{-1}\right)$.

Experiment $1 \quad$ Experiment $2 \quad$ Experiment 3

Feedstuff

$\begin{array}{lccc}\text { Manioc } & 330 & 341 & 303 \\ \text { Barley } & 125 & - & - \\ \text { Wheat } & - & 150 & - \\ \text { Maize } & - & - & 180 \\ \text { Soybeanmeal solv. extr. (CP: } 490 \mathrm{~g} \mathrm{~kg}^{-1} \text { ) } & 75 & 95 & - \\ \text { Soyabeanmeal solv. extr. (CP: } 410 \mathrm{~g} \mathrm{~kg}^{-1} \text { ) } & - & - & 55 \\ \text { Hominy feed (USA) } & 70 & 90 & 150 \\ \text { Wheat bran } & 150 & 150 & - \\ \text { Maize gluten feed (USA) } & - & - & 110 \\ \text { Peas } & 130 & 85 & 100 \\ \text { Meat meal tankage } & 24 & - & 25 \\ \text { Hemoglobine powder } & 20 & - & - \\ \text { Cane molasses } & 40 & 40 & 50 \\ \text { Animal fat } & 15.7 & 20 & - \\ \text { Limestone } & 9 & 12 & 7 \\ \text { Dicalciumphosphate } & 5.6 & 7 & 7 \\ \text { Sodium chloride } & 2.5 & 2.5 & 2.5 \\ \text { Other minerals and vitamins } & 1.52 & 1.52 & 3.52 \\ \text { L-lysine HCl (78 \%) } & - & 3.10 & 1.70 \\ \text { DL-methionine } & - & 1.50 & 1.05 \\ \text { L-threonine } & 0.64 & - & - \\ \text { DL-tryptophan } & 0.20 & 0.50 & 0.90 \\ \text { L-isoleucine } & 0.82 & 0.70 & \end{array}$

\section{Analysed content}

$\begin{array}{lccc}\text { Dry matter } & 871 & 875 & 873 \\ \text { Crude protein } & 162 & 137 & 136 \\ \text { Ash } & 67 & 65 & 69 \\ \text { Crude fat } & 33 & 34 & 27 \\ \text { Crude fibre } & 46 & 40 & 47 \\ \text { Net energy }\left(\mathrm{MJ} \mathrm{kg-1}^{-1} \mathrm{NE}_{\mathrm{f}}\right) & 8.82 & 9.04 & 8.97 \\ \mathrm{CA} & 8.0 & 7.7 & 7.9 \\ \mathrm{P} & 5.9 & 6.0 & 6.0 \\ & & & \\ \text { Lysine } & 8.8 & 8.6 & 8.6 \\ \text { Methionine } & 2.1 & 3.0 & 3.4 \\ \text { Methionine }+ \text { cystine } & 4.5 & 5.6 & 5.7 \\ \text { Threonine } & 6.5 & 4.7 & 6.0 \\ \text { Tryptophan } & 2.0 & 1.8 & 1.15 \\ \text { Isoleucine } & 6.3 & 5.8 & 5.7\end{array}$

ness was measured ultrasonically. After slaughter the carcasses were dissected according to a commercial method in order to determine percentage of meat and fat in the animals.

The apparent faecal digestibility of the diets was determined in digestibility ex- 
periments at the Research Institute in Lelystad. Each digestibility experiment was performed with 4 male pigs in metabolism cages, using a quantitative collection method (7 days adaptation period, 10 days collection period). The live weight of the pigs was between 70 and $100 \mathrm{~kg}$. In the digestibility experiments the apparent digestibility of proximate components and amino acids was determined in the diets 1 and 4 of Experiment 1, in diet 4 of Experiment 2 and in diet 3 of Experiment 3. From this the digestibility of the experimental amino acid in the other diets was calculated by assuming that the supplemented experimental amino acid was $100 \%$ digestible. From chemical composition and digestibility of proximate components the net energy of the diets was calculated according to the Rostock method (CVB, 1988).

Apart from the faecal digestibility of amino acids, determined in the digestibility experiments, dietary apparent ileal digestible amino acid concentrations have been calculated as well. This was done, because it is recognized, that ileal digestibility is in general the preferable estimate for available amino acids (van Weerden, 1989). The calculations were based upon the amino acid concentrations in the feedstuffs used and the ileal digestibility coefficients, as listed by CVB (1990).

\section{Chemical analyses}

Samples of the diets were taken at the feed mill after preparing the diets and during the feeding and digestibility experiments. They were analysed at the Research Institute in Lelystad. Faeces were analysed as fresh material (nitrogen), as air-dry material (other Weende components) and as freeze-dried material (amino acids). Nitrogen was analysed by the Kjeldahl method. Amino acids (excluding tryptophan) were analysed by ion-exchange column chromatography after hydrolysis for $23 \mathrm{~h} \mathrm{in} \mathrm{HCl}$ $\left(6 \mathrm{~mol} \mathrm{1}^{-1}\right)$ based on the method of Schram et al. (1953) and using correction factors for threonine, serine, valine and isoleucine according to Slump (1969). Cystine and methionine were determined as cysteïc acid and methionine sulphone according to the method of Schram et al. (1954). For the latter amino acids, samples were oxidized by performic acid prior to hydrolysis. Tryptophan was determined in a hydrolysate, obtained by $12 \mathrm{~h}$ oxygen-free hydrolysis under vacuum in $4 \mathrm{~mol} \mathrm{l}^{-1}$ lithium hydroxide in the presence of starch, by means of reversed-phase liquid chromatography over a C18 (Hypersil) column and detection by UV by $217 \mathrm{~nm}$ (Sato et al., 1984).

\section{Statistical analyses}

Feed intake, daily growth rate, feed conversion ratio and carcass quality except grading were subjected to analysis of variance procedures appropriate for randomized complete-block design with sex and the amino acid under study as treatment factors, using the statistical package GENSTAT 5 (Payne et al., 1987). Treatment sums of squares were subdivided into linear, quadratic and cubic components. Treatment means were compared by Student's $t$-tests. For daily gain, feed intake and feed conversion ratio analyses were done for the growing phase (up to $65 \mathrm{~kg}$ ), for the finishing phase (from $65 \mathrm{~kg}$ ) and for the whole experimental period. To esti- 
mate requirement figures, additional regression analysis was made according to a quadratic equation, and $95 \%$ confidence intervals were calculated. This appeared only to be meaningful in Experiment 2 .

\section{Results}

\section{Digestibility and feeding value}

The apparent faecal digestibilities of proximate components and main essential amino acids in the diets of the three experiments are shown in Table 3. Based on these data the concentrations of faecal digestible experimental amino acid in the diets of the three experiments are given (Table 4). In the same way the concentration of fae-

Table 3. Mean and standard deviation of apparent faecal digestibility coefficients ( $\%$ ) of proximate components and main essential amino acids in the diets examined.

\begin{tabular}{|c|c|c|c|c|}
\hline \multirow[t]{2}{*}{ Components } & \multicolumn{2}{|c|}{ Experiment 1} & \multirow{2}{*}{$\begin{array}{l}\text { Experiment } 2 \\
\text { diet } 4\end{array}$} & \multirow{2}{*}{$\begin{array}{l}\text { Experiment } 3 \\
\text { diet } 3\end{array}$} \\
\hline & diet 1 & $\operatorname{diet} 4$ & & \\
\hline Dry matter & $80.2 \pm 0.5$ & $81.3 \pm 0.7$ & $81.6 \pm 0.6$ & $83.3 \pm 0.4$ \\
\hline Organic matter & $84.1 \pm 0.4$ & $84.8 \pm 0.5$ & $84.9 \pm 0.7$ & $87.0 \pm 0.4$ \\
\hline Crude protein & $80.3 \pm 1.7$ & $80.8 \pm 1.1$ & $78.1 \pm 0.4$ & $78.8 \pm 2.0$ \\
\hline Crude fat & $83.7 \pm 1.4$ & $83.7 \pm 0.9$ & $80.7 \pm 1.1$ & $82.0 \pm 2.5$ \\
\hline Crude fibre & $38.8 \pm 2.8$ & $39.3 \pm 4.0$ & $34.3 \pm 3.2$ & $58.1 \pm 2.0$ \\
\hline Lysine & $81.5 \pm 2.1$ & $81.2 \pm 0.8$ & $82.5 \pm 0.3$ & $83.9 \pm 2.2$ \\
\hline Methionine & $74.3 \pm 1.6$ & $81.8 \pm 1.0$ & $83.9 \pm 0.2$ & $86.2 \pm 1.5$ \\
\hline Cystine & $78.5 \pm 1.0$ & $79.3 \pm 1.0$ & $81.3 \pm 2.2$ & $78.7 \pm 1.3$ \\
\hline Threonine & $79.2 \pm 1.3$ & $78.9 \pm 1.6$ & $79.8 \pm 1.1$ & $80.3 \pm 2.4$ \\
\hline Tryptophan & - & - & $83.6 \pm 1.1$ & $82.2 \pm 2.2$ \\
\hline Isoleucine & $78.8 \pm 1.6$ & $78.9 \pm 1.1$ & $79.6 \pm 1.5$ & $81.0 \pm 1.9$ \\
\hline
\end{tabular}

Table 4. Concentration of apparent faecal digestible experimental amino acid in the diets of the three experiments $\left(\mathrm{g} \mathrm{kg}^{-1}\right)$.

Diet $1 \quad$ Diet $2 \quad$ Diet $3 \quad$ Diet 4

Experiment 1

Digestible methionine

Digestible cystine

Digestible methionine + cystine

Experiment 2

Digestible threonine

3.5

1.6

1.9

3.5

3.8

4.0

4.5

5.0

Experiment 3

Digestible tryptophan

0.90

1.10

1.35

1.60 
cal digestible lysine was calculated. This was $7.2,7.1$ and $7.2 \mathrm{~g} \mathrm{~kg}^{-1}$ in the diets of Experiment 1, Experiment 2 and Experiment 3, respectively. Faecal digestible methionine + cystine contents in the diets of Experiment 2 and Experiment 3 were 4.6 and $4.7 \mathrm{~g} \mathrm{~kg}^{-1}$, respectively.

Net energy content of the diets was similar for all experiments (Table 2).

Concerning apparent ileal digestible lysine, concentrations of 7.3, 7.4 and 7.3 g $\mathrm{kg}^{-1}$ were calculated in the diets of the Experiments 1,2 and 3, respectively. The apparent ileal digestible concentrations of other important amino acids were calculated to be as follows: methionine + cystine: $4.4 \mathrm{~g} \mathrm{~kg}^{-1}$ in both the diets of Experiment 2 and 3; threonine: 4.7 and $4.3 \mathrm{~g} \mathrm{~kg}^{-1}$ in the diets of Experiment 1 and 3, respectively; tryptophan: $1.5 \mathrm{~g} \mathrm{~kg}^{-1}$ in both the diets of Experiment 1 and 2 .

\section{Health and culling}

In total, three pigs died in the experiments: two in Experiment 1 (at about $40 \mathrm{~kg}$ live weight) and one in Experiment 3 (at $100 \mathrm{~kg}$ live weight); the latter animal was not excluded from the statistical analysis. Some pigs suffered from diarrhoea and pneumonia, mainly in the Experiment 1 and 2 . After veterinary treatment, most animals recovered within one week. In the case of severe growth retardation the week concerned was left out of the calculations. No relation could be found between experimental treatment and illness. In Experiment 3, 8 out of 16 pigs on experimental diet 1 (1.15 $\mathrm{g} \mathrm{kg}^{-1}$ tryptophan) were discarded because of poor growth, feed intake and quality of legs. Dissection of two of the pigs showed many oedemata in the body. The other six animals were switched over to a starter feed or experimental diet 4 between 50 and $90 \mathrm{~kg}$ live weight, after which they recovered very quickly.

\section{Growth performance (all experiments)}

Feed intake, growth rate and feed conversion ratio are presented in Tables 5, 6 and 7 for Experiment 1,2 and 3, respectively. Growth performance of the pigs was good in all experiments: in the optimally supplemented experimental groups average daily gain amounted to 875 grams at an average feed conversion ratio of 2.84. Data about carcass quality, i.e. grading, backfat thickness and meat- and fat percentage for the three experiments are given in Table 8 .

From the Tables 5, 6 and 7 it appears that in all experiments for daily gain and feed conversion ratio the response of the pigs upon increasing amounts of the experimental amino acid was bigger in the growing phase than in the finishing phase, in both boars and gilts. The effects were mostly linear in character, with an additional quadratic component mainly in the growing phase, indicating a stabilization or worsening of performance at the highest level.

There was a clear sex-effect showing a better growth performance of the boars, in agreement with the findings of o.a. Campbell et al. (1988), but there were hardly any interactions between sex and experimental amino acid. No significant sex-effect was observed for feed intake, except small effects in the growing phase in Experiment 2 and in the finishing phase in Experiment 3 (higher feed intake by boars). 


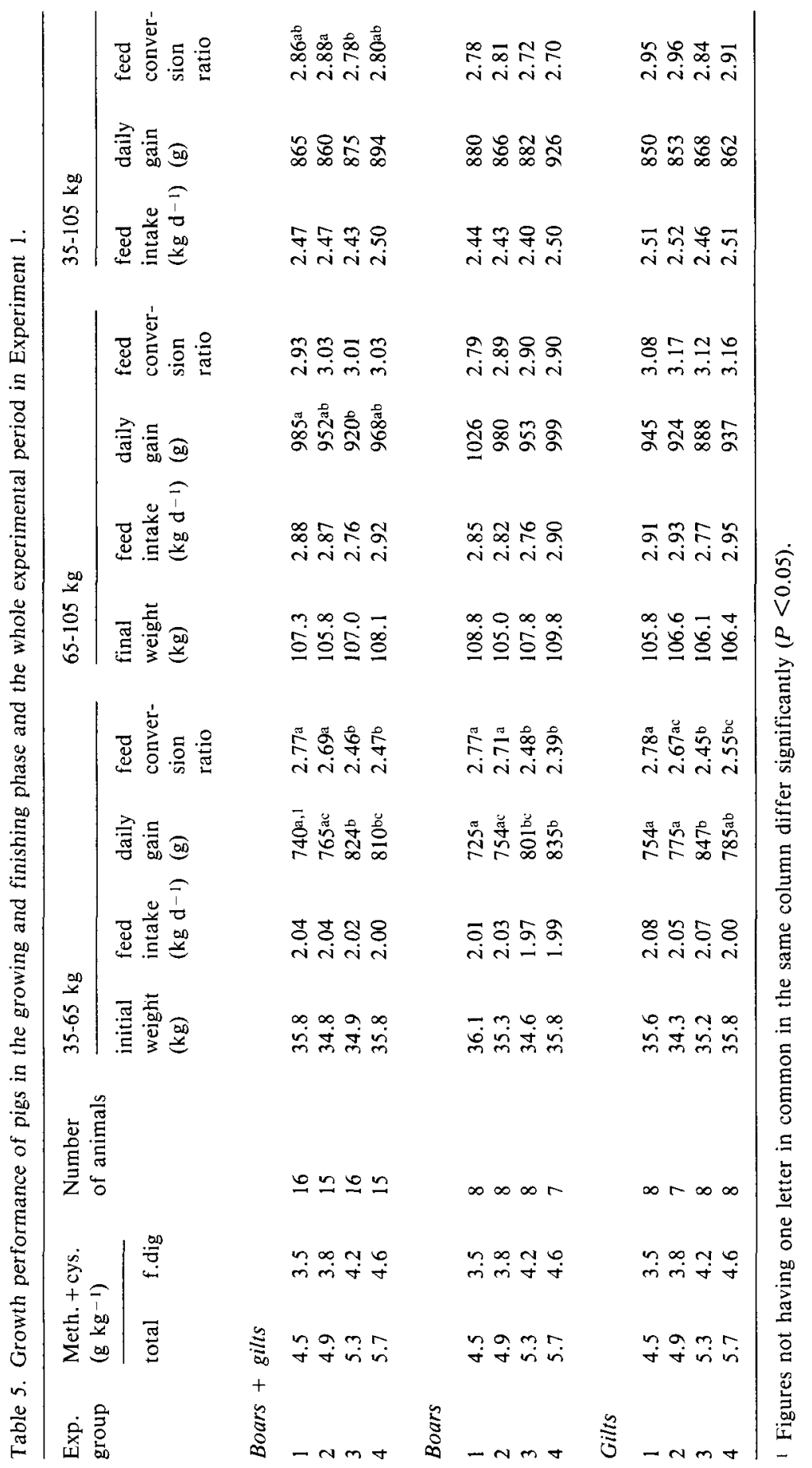




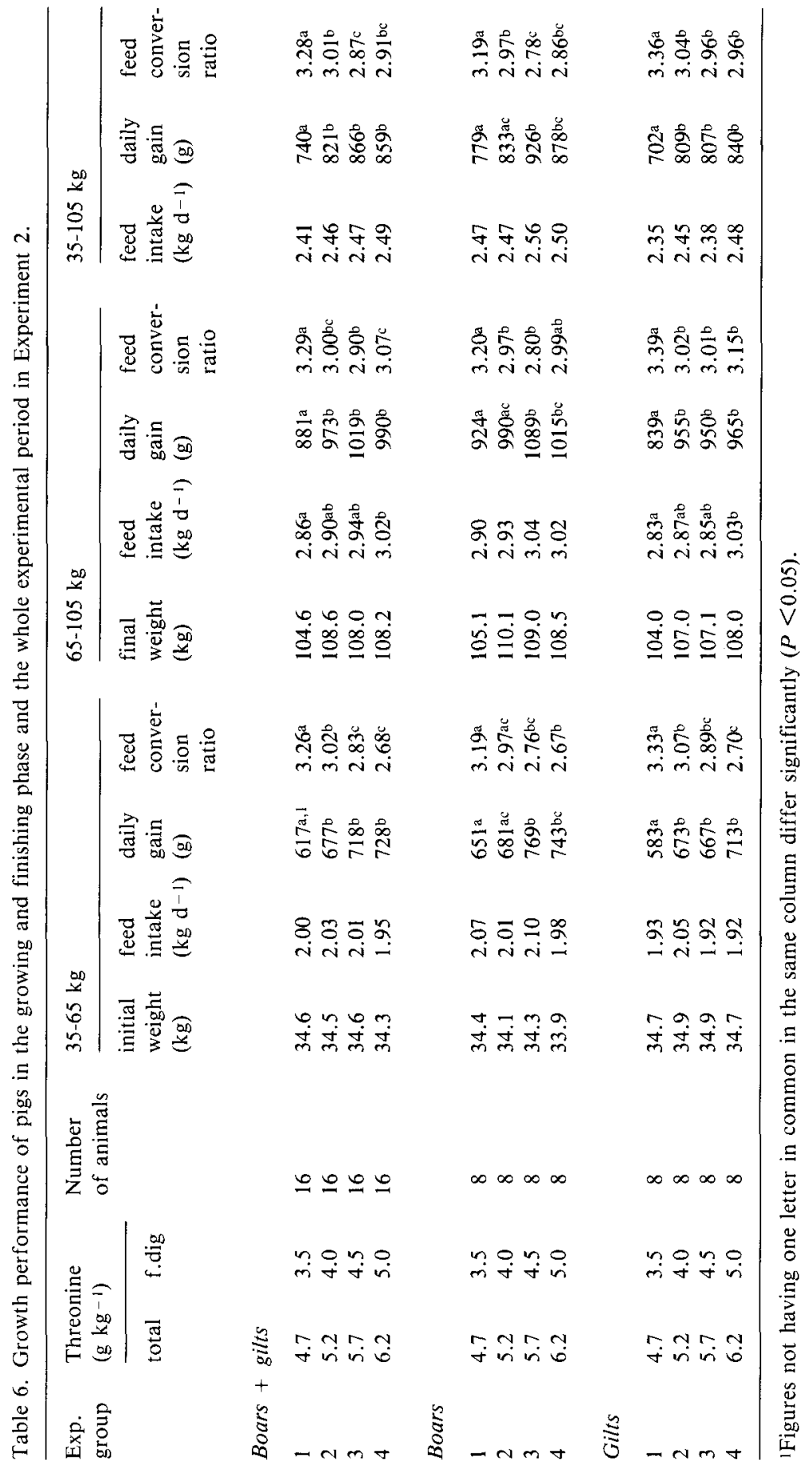




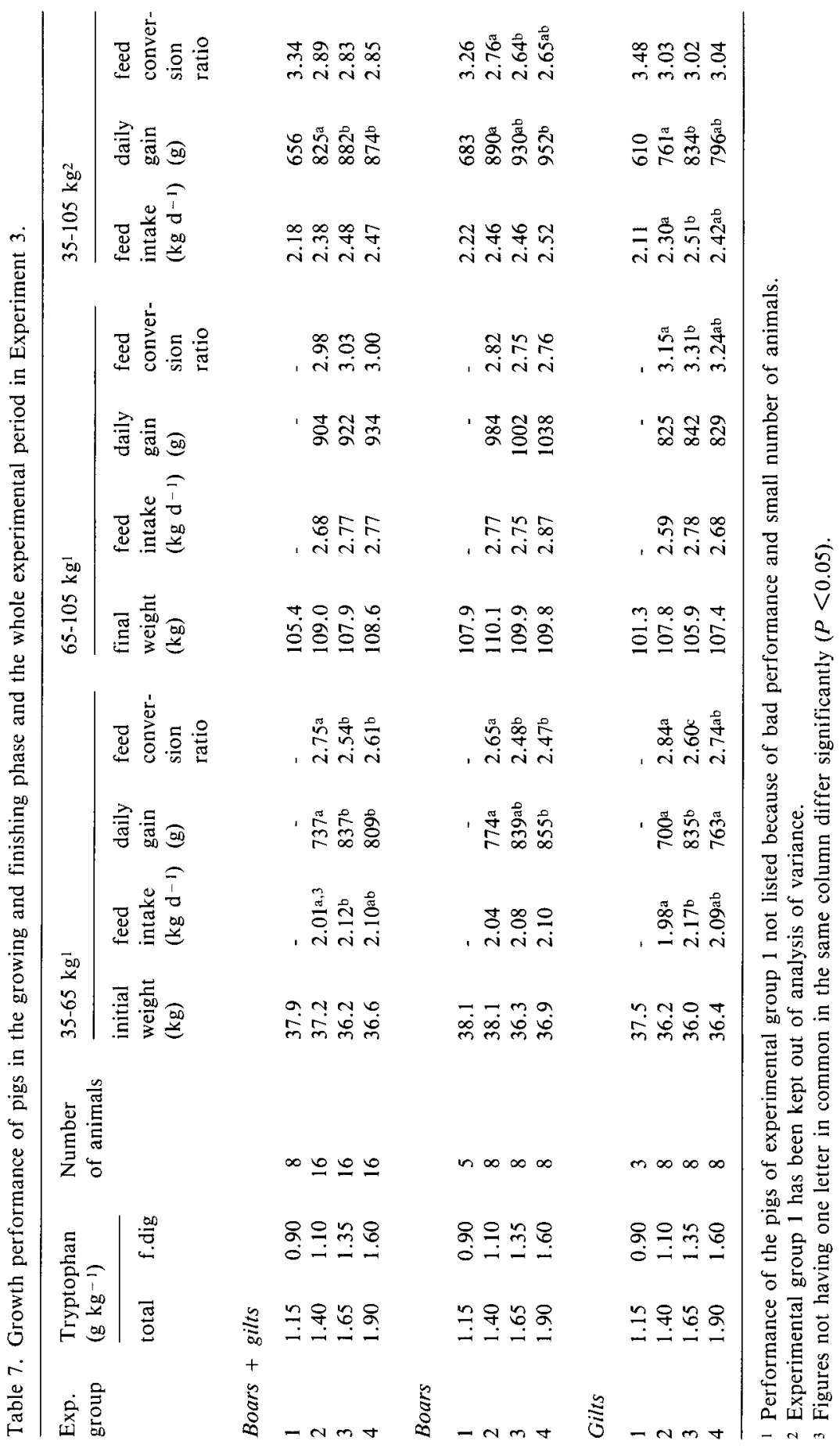


N. P. LENIS, J. TH. M. VAN DIEPEN AND P. W. GOEDHART

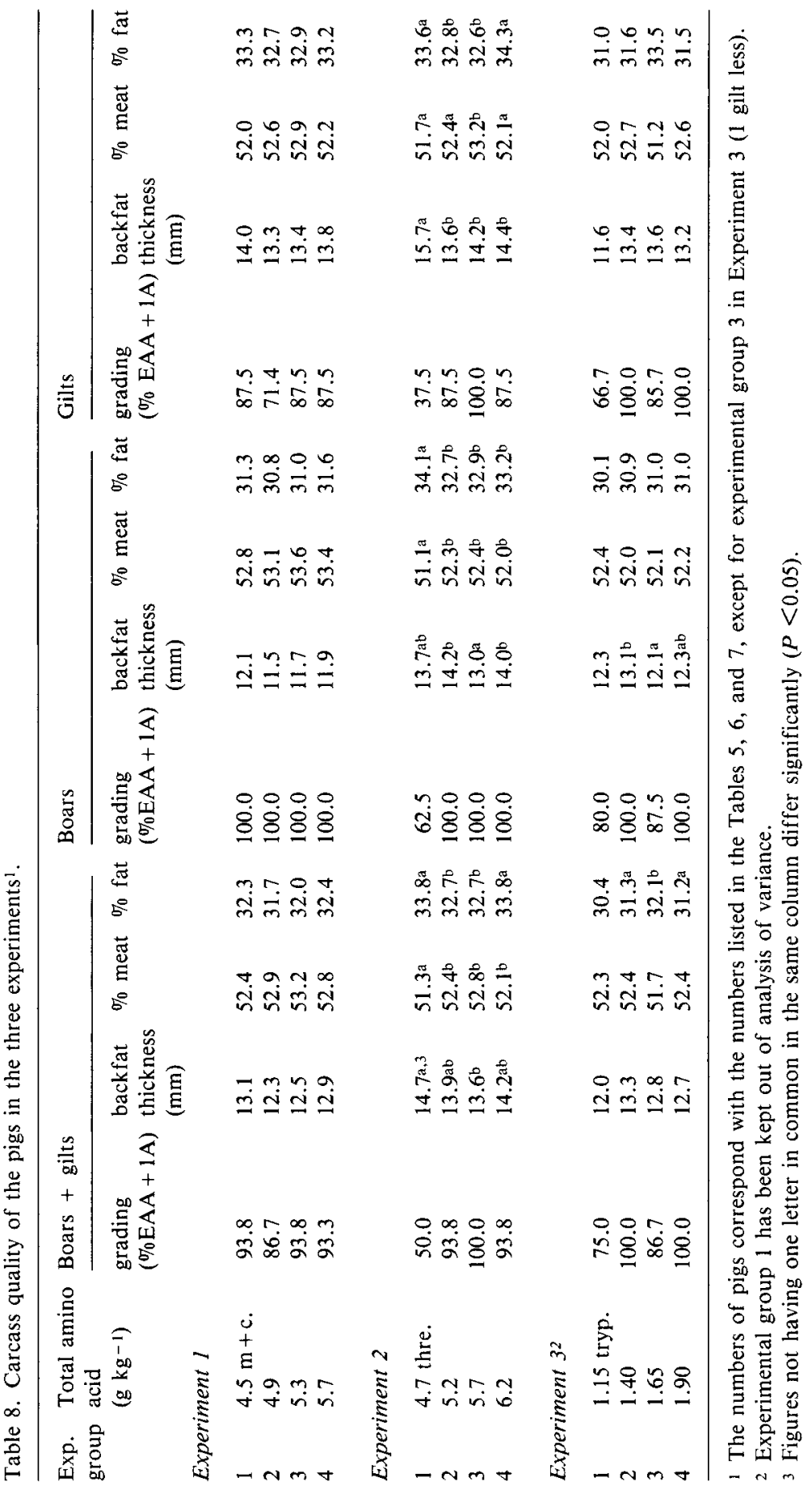


The effect of the experimental amino acid on carcass quality (Table 8) was much less than its effect on growth performance. Only in Experiment 2 were significant negative effects on carcass quality observed at the lowest threonine level. Despite a better feed conversion ratio, boars were not superior to gilts in carcass quality, except in Experiment 1. The carcasses of the boars did contain a larger proportion of bones, head and legs.

The main results of the separate experiments are described below.

\section{Experiment 1 (methionine + cystine)}

In the growing phase, growth rate and feed conversion ratio were significantly improved by methionine addition $(P<0.005$ and $P<0.001$, respectively). Increases in total methionine + cystine up to $5.7 \mathrm{~g} \mathrm{~kg}^{-1}$ and $5.3 \mathrm{~g} \mathrm{~kg}^{-1}$ improved growth performance for boars and gilts, respectively (Table 5). The effects were linear ( $P$ $<0.001$ ), with also a cubic trend for feed conversion ratio. In the finishing phase, growth performance was very high in all groups and was unaffected by methionine addition.

For the whole experimental period, growth rate was unaffected by methionine addition, but the most efficient feed conversion ratio was found for experimental group 3 , being $5.3 \mathrm{~g} \mathrm{~kg}^{-1}$ total methionine + cystine. Methionine did not affect feed intake (Table 5) and carcass quality (Table 8) significantly. Carcass quality was better for boars than for gilts.

\section{Experiment 2 (threonine)}

In both growing and finishing phase (Table 6) a significant effect of threonine addition was observed for growth rate $(P=0.002$ and $P<0.001$, respectively) and for feed conversion ratio $(P<0.001)$. The effects were linear $(P<0.001)$ with a quadratic effect on growth rate $(P=0.01)$ and feed conversion ratio $(P<0.001)$ in the finishing phase.

In the growing phase there was a significant growth rate response in boars up to the level of experimental group 3 , being $5.7 \mathrm{~g} \mathrm{~kg}^{-1}$ total threonine and for gilts up to the level of experimental group 2 , being $5.2 \mathrm{~g} \mathrm{~kg}^{-1}$ total threonine, whilst the most efficient feed conversion ratio was found at the highest level of addition (6.2 $\mathrm{g} \mathrm{kg}^{-1}$ total threonine) for both sexes.

During the finishing phase, both maximum growth rate and maximum feed conversion ratio were attained for boars at the level of experimental group 3, being 5.7 $\mathrm{g} \mathrm{kg}^{-1}$ total threonine, and for gilts at the level of experimental group 2, being 5.2 $\mathrm{g} \mathrm{kg}^{-1}$ total threonine. At the highest threonine level, feed conversion ratio increased again (quadratic effect). For the whole experimental period, maximum growth performance for the boars was attained at $5.7 \mathrm{~g} \mathrm{~kg}^{-1}$ total threonine; above this level there was a trend for worsening of growth performance. In the gilts the effect of additional threonine was less: only a favourable effect on feed conversion ratio was found above $5.2 \mathrm{~g} \mathrm{~kg}^{-1}$ total threonine.

There was a trend $(P=0.1)$ for a positive effect of threonine addition on feed 
intake in the finishing phase. This was caused mainly by the high feed intake of the gilts of experimental group 4 . The lowest threonine level had a significantly negative effect on all parameters for carcass quality $(P<0.01-P<0.001)$.

\section{Experiment 3 (tryptophan)}

Growth performance of the pigs was very poor at the lowest tryptophan level (1.15 $\mathrm{g} \mathrm{kg}^{-1}$ total tryptophan) (Table 7). Therefore 8 of the 16 pigs with the worst performance were taken out of the experiment prematurely. Performance, including feed intake, of the remaining 8 pigs was poor during the whole experimental period. The results have been kept out of the analysis of variance because of the small number of animals.

For the growing phase the analysis of variance of effects of tryptophan addition showed a very significant effect on growth rate $(P=0.001)$ and feed conversion ratio $(P<0.001)$. The response was both linear $(P=0.007$ and $P=0.002$, respectively) and quadratic ( $P=0.005$ and $P<0.001$, respectively). For both sexes there was a response of additional tryptophan up to the level of experimental group 3 (1.65 $\mathrm{g} \mathrm{kg}^{-1}$ total tryptophan). A further increase in tryptophan level (experimental group 4) decreased growth performance of the gilts significantly (quadratic effect).

For the finishing phase the analysis of variance of effects of tryptophan addition did not show significant effects on growth performance. Concerning feed conversion ratio, this was due to the fact that boars and gilts responded differently showing a trend $(P=0.1)$ for a quadratic sex-tryptophan interaction: in the boars, feed conversion ratio improved up to the level of experimental group 3 , being $1.65 \mathrm{~g} \mathrm{~kg}^{-1}$ total tryptophan. In the gilts, experimental group $2\left(1.40 \mathrm{~g} \mathrm{~kg}^{-1}\right.$ total tryptophan) showed the most favourable feed conversion ratio. The feed conversion ratio of experimental group 3 of the gilts was significantly higher. Growth rate was not improved by tryptophan addition above $1.40 \mathrm{~g} \mathrm{~kg}^{-1}$ total tryptophan. There was no sex-tryptophan interaction for growth rate.

For the whole experimental period, growth performance of the pigs responded up to a maximum of $1.65 \mathrm{~g} \mathrm{~kg}^{-1}$ total tryptophan, except feed conversion ratio of the gilts, which was not improved above $1.40 \mathrm{~g} \mathrm{~kg}^{-1}$ total tryptophan. Apart from the big effect of the lowest tryptophan level on feed intake, tryptophan also negatively affected feed intake of the gilts in experimental group 2, not in the boars. Feed intake of the gilts was highest in experimental group 3 , being $1.65 \mathrm{~g} \mathrm{~kg}^{-1}$ total tryptophan, both in the growing and in the finishing phase. Carcass quality was hardly affected by tryptophan.

\section{Discussion}

\section{Dietary amino acid levels}

In these experiments, diets have been supplemented with lysine, methionine, threonine, tryptophan and isoleucine in order to be sure that no other amino acids than 
the amino acid studied were limiting. The analysed dietary concentrations of these amino acids, on a total basis (Table 2) and on a digestible basis (Table 3), are supposed to be sufficient for good growth performance of the pigs (Lenis, 1989). Possibly, (digestible) lysine supply in the growing phase was not quite optimal for maximum protein deposition of the boars (Yen et al., 1986a, b; Fuller et al., 1986). This could be the reason why the boars, in spite of a better feed conversion ratio, were not superior to gilts in carcass quality, except in Experiment 1. Williams et al. (1984), however, in studies with pigs with a similar level of growth performance, concluded that approximately $8.6 \mathrm{~g} \mathrm{~kg}^{-1}$ lysine in the diet of pigs between $25-55 \mathrm{~kg}$ live weight, was sufficient for maximum growth performance. In our studies the experiments started even later, at $35 \mathrm{~kg}$.

Surprisingly, apparent faecal digestible lysine level was $0.2 \mathrm{~g} \mathrm{~kg}^{-1}$ lower than the calculated apparent ileal digestible level, contrary to what is observed commonly (Lenis, 1983; van Weerden et al., 1985; CVB, 1984, 1990). An explanation for this may be the fact that in our studies observed faecal amino acid digestibility was 2-3 points lower than calculated and the ileal digestible levels have been calculated from a table.

The estimates of the amino acid requirements from the three experiments can be expressed in proportion to lysine supply. Doing so makes only sense if the lysine supply corresponds with the requirement for lysine of the pigs. It is estimated that this was approximately the case in these experiments (Lenis, 1989). Therefore estimates of requirements are expressed in proportion to the lysine levels in the respective experiments. This is not done for ileal digestible amino acids, because these values were only calculated.

\section{Experiment I (methionine + cystine)}

On the basis of feed conversion ratio the requirement for total methionine + cystine of pigs in the live weight range $35-105 \mathrm{~kg}$ was estimated to be $5.3 \mathrm{~g} \mathrm{~kg}^{-1}$ diet (Table 5). Expressed as faecal digestible methionine + cystine this corresponds with 4.2 $\mathrm{g} \mathrm{kg}^{-1}$ diet. The corresponding calculated ileal digestible methionine + cystine level amounts also $4.2 \mathrm{~g} \mathrm{~kg}^{-1}$ diet. On a total basis, an optimum ratio of approximately $60 \%$ relative to dietary lysine supply was calculated. This is in accordance with the estimates of Günther \& Badewien (1987), Roth \& Kirchgessner (1987) and Fuller et al. (1989), who gave values of $60 \%, 55-57 \%$ and $59 \%$, respectively. It is, however, much lower than the $75 \%$ reported by Chung et al. (1989) for finishing pigs. In the latter study, total sulfur amino acid requirement was found to be 4.5 $\mathrm{g} \mathrm{kg}^{-1}$ diet, whilst total lysine requirement was put at $6.0 \mathrm{~g} \mathrm{~kg}^{-1}$ diet (NRC, 1988).

In our study the difference in feed conversion ratio between experimental groups 2 and 3 was bigger than between experimental groups 1 and 2, suggesting that the proportion of methionine in the total contents of $\mathrm{S}$ amino acid in experimental diet $1(47 \%)$ and in diet $2(51 \%)$ was not sufficient for optimum growth performance. This is even higher than results of recent experiments, which show that the methionine/cystine ratio should be $45 \%$ to $50 \%$ as a minimum. Roth \& Kirchgessner (1987) concluded $45 \%$, Fuller et al. (1989) $46 \%$ and Schutte (1989) $50 \%$, being 
the minimum share of methionine in total $\mathrm{S}$ amino acid needs.

In the finishing phase, growth performance was unaffected by methionine addition or methionine/cystine ratio. There was a trend for even the best feed conversion ratio at the lowest methionine + cystine level (compensatory effects) in both boars and gilts. As cyst(e)ine can supply about $80 \%$ of the total $\mathrm{S}$ amino acids required for maintenance (Fuller et al., 1989), one could expect the methionine/cystine ratio to be less important in finishing pigs. Apparently, a total concentration of $2.4 \mathrm{~g}$ $\mathrm{kg}^{-1}$ cystine and $2.1 \mathrm{~g} \mathrm{~kg}^{-1}$ methionine in the diet was sufficient for the finishing pigs.

\section{Experiment 2 (threonine)}

The requirement for total threonine of boars and gilts together in the live weight range $35-105 \mathrm{~kg}$ was estimated to be $5.7 \mathrm{~g} \mathrm{~kg}^{-1}$ diet (Table 6), corresponding with $4.5 \mathrm{~g} \mathrm{~kg}^{-1}$ faecal digestible threonine. Expressed as calculated ileal digestible threonine, this corresponds with $4.2 \mathrm{~g} \mathrm{~kg}^{-1}$ diet. From regression analysis it was estimated that for obtaining minimum feed conversion ratio the dietary content of total threonine over the whole experimental period should be $5.8 \mathrm{~g} \mathrm{~kg}^{-1}(95 \%$ confidence interval 5.7-6.4 $\mathrm{g} \mathrm{kg}^{-1}$ ) and for maximum weight gain even $5.9 \mathrm{~g} \mathrm{~kg}^{-1}$ (95\% confidence interval 5.7-7.8 $\mathrm{g} \mathrm{kg}^{-1}$ ) with only minor differences between boars and gilts. Based on the estimate of $5.7 \mathrm{~g} \mathrm{~kg}^{-1}$ total threonine, an optimum ratio of approximately $66 \%$ relative to total lysine supply was calculated. The threonine/lysine ratio found in our study corresponds with the estimate $(65 \%)$ of Günther \& Badewien (1987) and with the recent estimate of Wang \& Fuller (1990) $(64 \%)$, but is lower than the estimates of Wang \& Fuller (1989) and Fuller et al. (1989) being $72 \%$ and $75 \%$, respectively.

The significant negative effect of the lowest threonine level on carcass quality (Table 8) was in accordance with the bad growth performance and normal feed intake of this group, indicating that threonine was limiting protein deposition. Nevertheless, the effect of threonine on carcass quality was much less than on growth performance, which was also observed by Taylor et al. (1982) and by Yen et al. (1986a) in an experiment on lysine.

\section{Experiment 3 (tryptophan)}

The requirement for total tryptophan of pigs in the live weight range $35-105 \mathrm{~kg}$ was estimated to be $1.65 \mathrm{~g} \mathrm{~kg}^{-1}$ diet (Table 7). Expressed as faecal digestible tryptophan, this corresponds with $1.35 \mathrm{~g} \mathrm{~kg}^{-1}$ diet. The corresponding calculated ileal digestible tryptophan level amounts also $1.35 \mathrm{~g} \mathrm{~kg}^{-1}$ diet. On a total basis an optimum ratio of approximately $19 \%$ relative to total lysine supply was calculated. This is in accordance with the estimates of Wang \& Fuller (1989) and Fuller et al. (1989), who found $18-19 \%$.

Concerning carcass quality it has to be mentioned that the bad growth performance of group 1 did not result in lower carcass quality, because feed intake was also at a much lower level. The lower feed intake of group $1(12 \%$ lower than in 
group 3) is of similar magnitude as reported by Henry et al. (1986), who measured in young pigs a $10 \%$ lower feed intake at $1.05 \mathrm{~g} \mathrm{~kg}^{-1}$ total tryptophan, compared to the higher levels of tryptophan.

\section{Conclusions}

From the experiments described here the following conclusions can be drawn:

- The methionine + cystine requirement of pigs between 35 and $105 \mathrm{~kg}$ was estimated to be $5.3 \mathrm{~g} \mathrm{~kg}^{-1}$ total methionine + cystine, $4.2 \mathrm{~g} \mathrm{~kg}^{-1}$ faecal digestible methionine + cystine and $4.2 \mathrm{~g} \mathrm{~kg}^{-1}$ calculated ileal digestible methionine + cystine. On a total basis the methionine + cystine requirement was approximately $60 \%$ relative to total lysine supply. On a faecal digestible basis this was approximately $58 \%$. In the growing phase methionine/cystine ratio should not be below $50 \%$. In the finishing phase compensatory effects were observed at the lowest level of methionine + cystine.

- The threonine requirement of pigs between 35 and $105 \mathrm{~kg}$ was estimated to be $5.7 \mathrm{~g} \mathrm{~kg}^{-1}$ total threonine, $4.5 \mathrm{~g} \mathrm{~kg}^{-1}$ faecal digestible threonine and $4.2 \mathrm{~g} \mathrm{~kg}^{-1}$ calculated ileal digestible threonine. On a total basis the threonine requirement was approximately $66 \%$ relative to total lysine supply. On a faecal digestible basis the requirement was approximately $63 \%$.

- The tryptophan requirement of pigs between 35 and $105 \mathrm{~kg}$ was estimated to be $1.65 \mathrm{~g} \mathrm{~kg}^{-1}$ total tryptophan, $1.35 \mathrm{~g} \mathrm{~kg}^{-1}$ faecal digestible tryptophan and $1.35 \mathrm{~g}$ $\mathrm{kg}^{-1}$ calculated ileal digestible tryptophan. On a total basis the tryptophan requirement was $19 \%$ relative to total lysine supply. On a faecal digestible basis this was almost $19 \%$. A total tryptophan level of $1.15 \mathrm{~g} \mathrm{~kg}^{-1}$ diet had a very depressive effect on feed intake and growth performance.

- In all experiments the effect of increasing levels of experimental amino acid on growth performance was bigger in the growing phase than in the finishing phase. The effect on carcass quality was much less than on growth performance.

\section{References}

ARC, 1981. The nutrient requirements of pigs. Commonwealth Agricultural Bureaux, Slough, $307 \mathrm{pp}$.

Baker, D. H., N. K. Allen, J. Boomgaardt, G. Graber \& H. W. Norton, 1971. Quantitative aspects of D- and L-tryptophan utilization by the young pig. Journal of Animal Science 33: 42-46.

Bourbon, D. \& Y. Henry, 1988. Besoin en lysine, selon le sexe, du porc en finition. Journées de la Recherche Porcine en France 20: 409-414.

Campbell, R. G., M. R. Taverner \& D. M. Curic, 1988. The effects of sex and live weight on the growing pig's response to dietary protein. Animal Production 46: 123-130.

Chung, T. K., O. A. Izquierdo, K. Hashimoto \& D. H. Baker, 1989. Methionine requirement for the finishing pig. Journal of Animal Science 67: 2677-2683.

CVB, 1984. Provisional table about faecal digestible amino acids in feedstuffs for pigs. (In Dutch). Centraal Veevoederbureau in Nederland, Lelystad, $7 \mathrm{pp}$.

CVB, 1988. Table on feedstuffs. Information about composition, digestibility and feeding value. (In Dutch.) Centraal Veevoederbureau in Nederland, Lelystad.

CVB, 1990. Table about apparent ileal digestible amino acids in feedstuffs for pigs. (In Dutch). Centraal Veevoederbureau in Nederland, Lelystad, $15 \mathrm{pp}$. 
Fuller, M. F., R. MacWilliam, T. C. Wang \& L. R. Giles, 1989. The optimum dietary amino acid pattern for growing pigs. 2. Requirements for maintenance and for tissue protein accretion. British Journal of Nutrition 62: 255-267.

Fuller, M. F., J. Wood, A. C. Brewer, K. Pennie \& R. MacWilliam, 1986. The responses of growing pigs to dietary lysine, as free lysine hydrochloride or in soya-bean meal, and the influence of food intake. Animal Production 43: 477-484.

Günther, K. D. \& E. Badewien, 1987. Zur Bedeutung von Methionin und Threonin in der Ernährung Ferkels und des Mastschweines bei Verwendung von Getreiderationen. Züchtungskunde 59: 378-391.

Henry, Y., P. H. Duée, A. Rérat \& R. Pion, 1986. Determination of tryptophan requirement for growing pigs between 15 and $40 \mathrm{~kg}$ live weight. Nutrition Reports International 34: 565-573.

Kiener, T., J. Lougnon \& J. C. Jugy, 1988. Contribution a l'étude du besoin en tryptophane du porc charcutier. Journées de la Recherche Porcine en France 40: 401-407.

Kirchgessner, M. \& F. X. Roth, 1985. Biologische Wirksamkeit von DL-tryptophan bei Mastschweinen. Zeitschrift für Tierphysiologie, Tierernährung und Futtermittelkunde 54: 135-141.

Lenis, N. P. 1983. Faecal amino acid digestibility in feedstuffs of pigs. In: R. Pion, M. Arnal \& D. Bonin (Eds), Proceedings 4th International Symposium on Protein Metabolism and Nutrition, ClermontFerrand (France), Vol. 2, p. 385-389. Institut National de la Recherche Agronomique, Paris.

Lenis, N. P., 1989. Lower nitrogen excretion in pig husbandry by feeding: current and future possibilities. Netherlands Journal of Agricultural Science 37: 61-70.

Lenis, N. P. \& S. H. M. Metz, 1984. The consequence of genetic improvement for protein and lysine requirements of growing pigs. In: T. Zebrowska, L. Buraczewska, S. Buraczewski, J. Kowalczyk \& B. Pastuszewski (Eds), Proceedings of the VIth International Symposium on Amino Acids, Serock, (Poland), p. 298-304. Polish Scientific Publishers, Warszawa.

Moughan, P. J. \& W. C. Smith, 1984. Assessment of a balance of dietary amino acids required to maximise protein utilisation in the growing pig (20-80 kg live weight). New Zealand Journal of Agricultural Research 27: 341-347.

NRC, 1988. Nutrient requirements of swine. National Research Council, 9th revised edition. National Academy Press, Washington, DC, 93 pp.

Payne, R. W., P. W. Lane, A. E. Ainsley, K. E. Bicknell, P. G. N. Digby, S. A. Harding, P. K. Leech, H. R. Simpson, A.D. Todd, P.J. Verrier, R.P. White, J. C. Gower, G. Tunnicliffe Wilson \& L. J. Paterson, 1987. Genstat 5 Reference Manual. Oxford University Press, New York, 749 pp.

Roth, F. X. \& M. Kirchgessner, 1987. Biological efficiency of dietary methionine or cystine supplementation with growing pigs. Journal of Animal Physiology and Animal Nutrition 58: 267-280.

Sato, H., T. Seino, T. Kobayashi, A. Murai \& Y. Yugari, 1984. Determination of the tryptophan content of feed and feedstuffs by ion exchange liquid chromatography. Agricultural and Biological Chemistry 48: 2961-2969.

Sauer, W. C. \& L. Ozimek, 1986. Digestibility of amino acids in swine: results and their practical applications. A review. Livestock Production Science 15: 367-388.

Schram, E., J. P. Dustin, A. Moore \& E. J. Bigwood, 1953. Application de la chromatographie sur echangeur d'ions à l'etude de la composition des aliments en acides aminés. Analytical Chimica Acta 9: 149-162.

Schram, E., S. Moore \& E. J. Bigwood, 1954. Chromatographic determination of cystine as cysteic acid. Biochemical Journal 57: 35-37.

Schutte, J. B. 1989. Practical application of (bio)-synthetic amino acids in poultry and pig diets. In: E. J. van Weerden \& J. Huisman (Eds), Nutrition and digestive physiology in monogastric farm animals, p. 75-88. Pudoc, Wageningen.

Schutte, J. B., E. J. van Weerden \& F. Koch 1988. Utilization of DL- and L-tryptophan in young pigs. Animal Production 46: 447-452.

Slump, P., 1969. Characterization of the nutritive value of food proteins by amino acid composition and the effect of heat and alkali treatment on the availability of amino acids. (In Dutch, English summary.) Doctoral thesis, Free University, Amsterdam, $131 \mathrm{pp}$.

Taylor, A. J., D. J. A. Cole \& D. Lewis, 1982. Amino acid requirements of growing pigs. 3. Threonine. Animal Production 34: 1-8.

Wang, T. C. \& M. F. Fuller, 1989. The optimum dietary amino acid pattern for growing pigs. 1. Experiments by amino acid deletion. British Journal of Nutrition 62: 77-89. 
Wang, T. C. \& M. F. Fuller, 1990. The effect of the plane of nutrition on the optimum dietary amino acid pattern for growing pigs. Animal Production 50: 155-164.

Weerden, E. J. van, 1989. Present and future developments in the protein/amino acid supply of monogastric animals. In: E. J. van Weerden \& J. Huisman (Eds), Nutrition and digestive physiology in monogastric farm animals, p. 89-101. Pudoc, Wageningen.

Weerden, E. J. van, J. Huisman, P. van Leeuwen \& P. Slump, 1985. The sensitivity of the ileal digestibility method as compared to the faecal digestibility method. In: A. Just, H. Jörgensen \& J. A. Fernandez (Eds), Proceedings 3rd International Seminar on Digestive Physiology in the Pig, Copenhagen, p. 392-395. National Institute of Aminal Science, Copenhagen.

Williams, W. D., G. L. Cromwell, T. S. Stahly \& J. R. Overfield, 1984. The lysine requirement for the growing boar versus barrow. Journal of Animal Science 58: 657-665.

Yen, H. T., D. J. A. Cole \& D. Lewis, 1986a. Amino acid requirements of growing pigs. 7. The response of pigs from 25 to $55 \mathrm{~kg}$ live weight to dietary ideal protein. Animal Production 43: 141-154.

Yen, H. T., D. J. A. Cole \& D. Lewis, 1986b. Amino acid requirements of growing pigs. 8. The response of pigs from 50 to $90 \mathrm{~kg}$ live weight to dietary ideal protein. Animal Production 43: 155-165. 